concept of property ownership, Darwin argued, "is common to every dog with a bone". With a directness and candour that still shocks today, Darwin mused that a dog's "deep love ... for his master, associated with complete submission, some fear, and perhaps other feelings" prefigures human feelings of religious devotion.

Townshend shows a deft touch with a considerable body of Darwin scholarship. However, her simplified account of how scientific attitudes to dog behaviour have changed since Darwin is less secure. She mainly blames "behaviourists" in animal psychology for ruling inadmissible Darwin's sympathetic attribution of human qualities to dogs, noting that anthropomorphism has been reinstated in recent years by "cognitive psychologists". However, the rejection of anthropomorphism was not limited to behaviourists and encompassed all forms of animal-behaviour study in the mid-twentieth century. Debate over the degree to which scientific terms used to describe human behaviour can be applied to animals continues to this day.

All in all, Darwin's Dogs is thoroughly entertaining and informative. It is the ideal antidote to Darwin fatigue.

Clive Wynne is associate professor of psychology at the University of Florida, PO Box 112250,

Gainesville, Florida 32601, USA, and author of Do Animals Think?

e-mail:wynne@ufl.edu

\title{
Forgotten treasure seeker
}

The Fossil Hunter: Dinosaurs, Evolution, and
the Woman Whose Discoveries Changed
The World
by Shelley Emling
Palgrave Macmillan: $2009.256 \mathrm{pp}$.
$\$ 27, £ 15.99$
Remarkable Creatures
by Tracy Chevalier
Dutton/HarperCollins: $2009.352 \mathrm{pp}$.
$\$ 26.95 / £ 15.99$

Until recently, histories of science were written almost entirely by, for and about men. The nineteenth-century hunt for Jurassic-era fossils along the beaches of the British town of Lyme Regis was no different. Although the names of naturalists such as Georges Cuvier, William Buckland and Richard Owen who used the fossils to overturn society's ideas about life on Earth are familiar, that of Mary Anning is only beginning to be exhumed. The publication of two books about her life - one factual, one fictional - will raise her profile in the public imagination.

Anning was a poor, working-class twelve- year-old when she made her first major discovery within the rocks of the perilous sea cliffs in 1811: the first complete skeleton of an ichthyosaur. She went on to uncover many other important fossils, such as the first plesiosaur and the first complete skeleton of the winged reptile Dimorphodon macronyx. Collecting and selling small fossils to earn a living, she also led fossil hunts for naturalists visiting Lyme Regis.

Anning's discoveries made it into the local newspapers. But it was the wealthy collectors and the established naturalists championing her finds in the halls of the Geological Society whose names became associated with them. Although her fossils helped overturn the popular idea that Earth and all its inhabitants were created in six days in $4004 \mathrm{BC}$, paving the way for Charles Darwin's great synthesis in 1859, Anning wasn't mentioned in key publications or lectures.

In her diligent biography The Fossil Hunter, Shelley Emling explains that in Anning's day women had no place in the cut and thrust of science. Urged not to appear outdoors without a chaperone, women were barred from places where learned debates took place and were thought to lack the intellectual rigour or stamina for fieldwork. Despite this, women did make vital contributions. Anning shared the beaches of Lyme Regis with three other female fossil collectors - the middle-class Philpott sisters, notably Elizabeth, who made well-regarded finds. And Emling describes the activity of two other talented nineteenth-century women, the wives of geologists William Buckland and Roderick Murchison, whose contributions included sketching and labelling of geological samples on expeditions.

But Anning was more than a collector or helper - she was a true scientist. She reconstructed and cleaned her own finds. She devoured scientific articles, often painstakingly copying out the entire text and figures. She engaged in spirited discussions with the men who sought her expertise and her samples. She dissected living sea creatures on the kitchen table to better understand the anatomy of their longdead counterparts. She even conducted research, surmising, for example,

that the rock-like bodies she often found within the skeletons she uncovered - coprolites were hardened faeces. Together with William Buckland, she reconstituted coprolites in her workshop and deduced what the animals had been eating.

Like many retrospective narratives, Anning's story has its heroes and anti-heroes, set-pieces and eureka moments. In Remarkable Creatures, Tracy Chevalier uses these devices to construct a fictionalized account of Anning's life. Able to make things up when the details are shrouded in obscurity, Chevalier's engaging version easily wins out over Emling's more faithful biography. Chevalier's unconstrained hand lets one suspend disbelief, such as in "[Buckland] asked so many questions ... that I began to feel like a pebble rolled back and forth in the tide". By contrast, confined by the facts, Emling's wearing reliance on the conditional

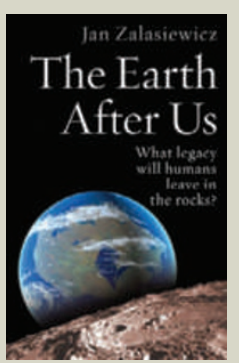

\section{The Earth After Us: What Legacy Will Humans} Leave in the Rocks?

by Jan Zalasiewicz (Oxford Univ. Press, $€ 8.99$ )

Using the imagined concept of extraterrestrial beings examining Earth for evidence that humanity ever existed, geologist Jan Zalasiewicz looks at what we might leave behind in the geological record. Describing the evidence we have for Earth's past, he explores our effects on the world and puts them in perspective over the vast timescale of the planet's history.
GILL MCKIBBEN

DEEP ECONOMY

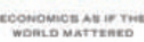
|||||||||||||

\section{Deep Economy: Economics as if the World Mattered} by Bill McKibben (Oneworld, $€ 9.99$ ) Bill McKibben calls for a new focus on developing local, rather than global, economies - advocating that cities and regions should produce more of their own food, energy and culture. Such small, local economies, he argues, offer a greater sense of community and satisfaction, and better protection against an increasingly uncertain future. 
perfect — in sentences such as “The bracing early-morning air would have invigorated Mary's senses" - soon begins to grate.

Emling's biography is the more thorough and complete work. It also frees us from the claustrophobic atmosphere of Lyme Regis, providing the context of discoveries happening elsewhere. Chevalier's tale glosses over most of Anning's later life. But so accurate was her fictional rendering that I felt I was reading the same book twice. Both works did, however, lack a gripping plot. Emling's solution was to incorporate peripheral dramas, such as natural disasters befalling Lyme Regis. Chevalier's strategy was to sneak Elizabeth Philpott into a key session of the Geographical Society and to give Anning a putative lover.

In the end, Anning's life story can offer no more than a pleasant but sedate read, either in fact or fiction. More evocative was the drama, brought out well in both works, of how her discoveries shook the world: leering, nightmarish monsters materializing from the clay and hinting at a world far more ancient, savage and uncaring than anyone could possibly have imagined.

Jennifer Rohn is a cell biologist at University College London, UK, and editor of LabLit.com.

Her first novel is Experimental Heart.

e-mail: jenny@lablit.com

\section{History of the hard stuff}

\section{Uncorking the Past: The Quest for Wine, Beer, and Other Alcoholic Beverages by Patrick E. McGovern \\ University of California Press: 2009. \\ 348 pp. \$29.95, £20.95}

Barley, wheat and grapes in the Middle East; rice, millet and hawthorn fruit in China; figs and dates in the Levant; sorghum and palm sap in Africa; maize, cacao, cactus fruit, manioc and pepper-tree fruit in the Americas; and everywhere, honey. All these substrates were used by early humans in their quest for alcohol.

In Uncorking the Past, biomolecular archaeologist and University of Pennsylvania museum director Patrick McGovern argues that the desire for alcohol is innate in humans and other primates. Moreover, he believes that "the uniquely human traits" of self-consciousness, innovation, the arts and religion have been "encouraged by the consumption of an alcoholic beverage". This is a difficult proposition to prove. In trying to do so, McGovern takes his reader on a world tour, examining the archaeological record for alcohol use across continents and cultures, searching for common themes that are indicative of universal use.

The earliest pottery artefacts with identifiable residues of a fermented beverage - arising from a mixed fermentation of rice, honey and hawthorn fruit - were found in China and date to 7000 BC. Three thousand miles away, in the Zagros mountains in western Iran, pottery dating to $3500 \mathrm{BC}$ has been found with residue of tartaric acid, indicating wine storage, as well as containers with a calcium oxalate 'beerstone' residue from barley beer. In Asia, Europe and the Americas, archaeologists have unearthed buildings that were constructed for the production and storage of various alcoholic beverages. And fermentation vessels and elaborate drinking sets are found in tombs of the rich and powerful across the world. Clearly, alcohol has been a part of human civilization for millennia. But has it played a part in the development of human culture?

McGovern narrates his thoughts in the first person, as if relating them to friends over a drink. He intertwines his own research findings - detailed in his earlier book, Ancient Wine with those of others, and tells stories of quests to recreate ancient beverages. He describes tasting 'Chateau Jiahu', a modern recreation of the earliest fermentation discovered in China; and the 'Phrygian Grog' he named 'Midas Touch', a fermented beverage based on wine grapes, honey and malted barley.
The residues of this were found in bronze containers in the burial chamber of a Phrygian king, perhaps Midas, near present-day

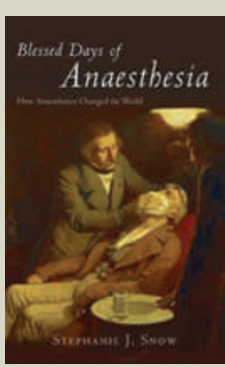

Blessed Days of Anaesthesia: How Anaesthetics Changed The World

by Stephanie J. Snow (Oxford Univ. Press, E9.99)

Stephanie Snow explores how early advances in

anaesthetics changed society. "[This] is not a real medical

history, nor is it seriously concerned with medicine or society beyond England and Scotland. But it seeks to link developments in anaesthesia with changing social, philosophical, scientific and religious attitudes in those countries," wrote John Carmody (Nature 456, 38; 2008).

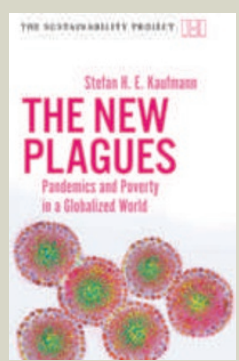

The New Plagues: Pandemics and Poverty in a Globalized World

by Stefan Kaufmann (Haus Publishing, £9.99)

An accessible and up-to-date look at diseases that are on the rise thanks to increased globalization. Describing the various strategies that agents such as microorganisms or prions might adopt, Stefan Kaufmann delves into the conflict between rich and poor in combating outbreaks, and looks at methods for containment. 